\title{
Interaction Effect of Genotype and Row Spacing in Chickpea and its Post Harvest Studies
}

\author{
Usha Waskle $^{1 *}$, R.P. Singh ${ }^{1}$ and Megha Dubey ${ }^{2}$ \\ ${ }^{1}$ Department of Agronomy R.A.K. College of Agriculture, Sehore 466001 (M.P.), India \\ 2 KVK, Betul, JNKVV (M.P.), India \\ *Corresponding author
}

\section{A B S T R A C T}

\begin{tabular}{|c|}
\hline Keywords \\
\hline $\begin{array}{l}\text { Genotypes, Yield } \\
\text { Characters, } \\
\text { Chickpea, } \\
\text { Variability }\end{array}$ \\
\hline Article Info \\
\hline $\begin{array}{l}\text { Accepted: } \\
\text { 17 October } 2019 \\
\text { Available Online: } \\
10 \text { November } 2019\end{array}$ \\
\hline
\end{tabular}

Chickpea or chana is a very important pulse crop that grows as a seed of a plant named Cicer arietinum in the Leguminosae family. Chickpea is a highly nutritious pulse and places third in the importance list of the food legumes that are cultivated throughout the world. It contains $25 \%$ proteins, which is the maximum provided by any pulse and $60 \%$ carbohydrates. Madhya Pradesh produces the major share of around $40 \%$ in the Indian production of around 6 million tons. Uttar Pradesh and Rajasthan follow Madhya Pradesh contributing to $16 \%$ and $14 \%$ of production respectively. Chickpea, to compare the production potential of six desi chickpea genotypes, (JG 16, JG 315, PhuleG 405, JG 36, NBeG 452 and RVG 203) at Row spacing $30 \mathrm{~cm}$ and $45 \mathrm{~cm}$. The experiment was laid out in randomized block Design with three replication and $5.0 \mathrm{~m} \times 3.6 \mathrm{~m}$ plot size. Chickpea (desi and kabuli) is an important pulse crop of India and research work has been conducted on different aspect at various places in the country. In present study found that seeds per pod were significantly superior in PhuleG 405 (1.68) than other genotypes except RVG 203. Plant dry weight $(\mathrm{g})$ was recorded under the variety JG $315(1.38,5.43,8.56$ and 11.56 g) at all the growth stages of crop viz., 30, 60, 90 DAS and at maturity respectively.

\section{Introduction}

Chickpea varieties play an important role in the production of pulses. Selection of variety for a set of agro-climatic condition is very important to achieve maximum potential because of different growth and development behaviour, it is only due to different genetic characters of variety. The major area of chickpea in Madhya Pradesh is under rainfed conditions. Proper germination and better establishment of the plants for normal plant population is an important factor responsible for getting optimum yield.

Row spacing is one of the important characters which can be manipulated to attain the maximum production from per unit land 
area. The optimum row spacing with proper geometry of planting is dependent on variety, its growth habit and agro climatic condition. The seed yield of chickpea is highly dependent on plant population. Seed yield increases with decreased row spacing upto an optimum limit which changes according to genotypes.

Goyal et. al (2010) Studied on growth and yield of kabuli chickpea (Cicer arietinum L.) genotype under different plant densities and fertility levels. Sharma and Dadheech (1986) reported higher seed yield $(15.69 \mathrm{q} / \mathrm{ha})$ with $30 \mathrm{~cm}$ row spacing while $45 \mathrm{~cm}$ row spacing reduced the yield (12.79 $\mathrm{q} / \mathrm{ha})$.

Beech and Leech (1989) studied growth and yield of chickpea at row spacing of 18,36,53 and $71 \mathrm{~cm}$. Row spacing had only a small effect on ground dry matter production and yield. There was no significant difference in yield at different row spacing. Present investigation study interaction of row spacing and genotype effect on chick pea and its post harvest studies.

\section{Materials and Methods}

The experiment was laid out in randomized block design with 12 treatments and each treatment was replicated three times (Table 1). The details of layout plan and treatments are given as follows:

\section{Treatment details (Table 2)}

\section{Genotypes (6)}

V1: JG-16

V2: JG-315

V3: PhuleG-405

V4: JG-36
V5: NBeG-452

V6: RVG-203

\section{Row spacing (2)}

\section{S1: $30 \mathrm{CM}$}

S2: $45 \mathrm{CM}$

\section{Treatment combinations}

In this investigation the crop growth rate was worked out with the help of following formula; as proposed by Watson (1952)

$\mathrm{CGR}=\frac{\mathrm{W}_{2}-\mathrm{W}_{1}}{\mathrm{P}\left(\mathrm{t}_{2}-\mathrm{t}_{1}\right)}$

Where,

$\mathrm{P}$ is ground area $\left(1 \mathrm{~m}^{2}\right)$;

$\mathrm{W}_{1}$ and $\mathrm{W}_{2}$ are plant dry weight at time $\mathrm{t}_{1}$ and $\mathrm{t}_{2}$, respectively.

The mean relative growth rate over a time interval from $t_{1}$ and $t_{2}$ was calculated with the help of following algebraic expression as proposed by Fisher (1921).

$\mathrm{RGR}=$

$$
\log _{\mathrm{e}} \mathrm{W}_{2}-\log _{\mathrm{e}} \mathrm{W}_{1}
$$

Where,

$\mathrm{W}_{1}$ and $\mathrm{W}_{2}$ are the dry weight $(\mathrm{g})$ at time $\mathrm{t}_{1}$ and $t_{2}$, respectively and $\log _{e}$ is natural $\log$.

In case of " $F$ " test was significant, standard error and critical differences were calculated by formula.

\section{Genotypes}

$S . E_{m} \pm=\frac{E M S}{R * S}$ 


$$
\begin{aligned}
& \text { C.D.at } 5 \%=S . E_{m} \pm \sqrt{t_{(22 d f)}} \text { at } 5 \% \\
& \text { C.V. } \%=\frac{\sqrt{E M S}}{G M} * 100
\end{aligned}
$$

Where:

$\mathrm{t}=$ Number of treatments
$\mathrm{R}=$ Number of replication
D.F. $=\quad$ Degree of freedom
S.Em $\pm=$ Standard error of mean
C.D. $\quad=$ Critical difference
C.V. $=$ Coefficient of variance
MSS = Mean Sum of square
SS $\quad=$ Sum of square
EMS = Error mean square

\section{Results and Discussion}

\section{Dry weight /plant (g)}

The dry weight per plant as a measure of crop growth was recorded at successive stages of crop growth i.e. $30,60,90$ DAS and maturity. The dry weight per plant at different growth stages is presented in Table 3. Varieties and row spacing was found significant differences in dry weight per plant at all the growth stages of crop growth. The variety PhuleG 405 gave maximum dry weight per plant $(1.58,5.94$, 8.97 and 11.75) which was significantly superior than RVG 203, NBeG 452, JG 16, JG 36 and JG 315 at all the growth stages of crop. The minimum plant dry weight (g) was recorded under the variety JG $315(1.38,5.43$, 8.56 and $11.56 \mathrm{~g}$ ) at all the growth stages of crop viz 30, 60, 90 DAS and at maturity respectively Beech, and Leech (1989). The effect of different row spacing on dry weight per plant was found significant at all the observations except 60 DAS.

The crop sown at $30 \mathrm{~cm}$ row spacing was significantly superior than $45 \mathrm{~cm}$ in dry weight of per plant at all stage of crop. The maximum dry weight per plant viz $(1.56,5.75$, 8.85 and $11.71 \mathrm{~g}$ ) was recorded when the crop was shown at $30 \mathrm{~cm}$ spacing in all the observation recorded at 30, 60, 90 and maturity stage respectively.

The interaction between genotypes and row spacing was found significant in all the observations recorded at 30,60, 90 DAS and at maturity at all stages.

It was observed that interaction between genotypes and row spacing in the relevance to per plant dry weight the genotype PhuleG 405 was found significant in all stages while it was observed that at 30 DAS, 60, 90 and at maturity (Syad et al., 2012) (Table 4-7).

\section{Post harvest studies}

\section{Number of pods / plant}

Genotypes exhibit differential pod bearing ability (Table 8) Genotypes PhuleG 405 produced significantly higher number of pods per plant than other genotypes (Khan et al., 2010). While it was at par with RVG 203. However, genotypes NBeG 452, JG 16, and JG 36 produced significantly more number of pods per plant as compared to JG 315. The data given in table 8 revealed that pod bearing ability of chickpea plant admirably increased as the row spacing decreased from 45 to 30 $\mathrm{cm}$. The $30 \mathrm{~cm}$ row spacing resulted in significantly higher number of pods/plant (53.92) over $45 \mathrm{~cm}$ row spacing. The interaction between genotypes and row spacing $(\mathrm{G} \times \mathrm{S})$ was found significant. 
Table.1

\begin{tabular}{|c|c|}
\hline Design & Randomized Block Design \\
\hline Treatments & 12 \\
\hline Replications & 3 \\
\hline Total number of plots & 36 \\
\hline Gross plot size & $5.0 \mathrm{~m} \times 3.6 \mathrm{~m}$ \\
\hline Net plot size & $4.5 \mathrm{~m} \times 2.7 \mathrm{~m}$ \\
\hline Distance between replications & $1.0 \mathrm{~m}$ \\
\hline Distance between plots & $0.50 \mathrm{~m}$ \\
\hline Crop & Chickpea \\
\hline Seed rate & $80 \mathrm{~kg} / \mathrm{ha}$ \\
\hline Distance between rows & As per treatment \\
Fertilizer dose & $20: 60: 20: 20(\mathrm{~N}: \mathrm{P}: \mathrm{K}: \mathrm{S} \mathrm{kg} / \mathrm{ha})$ \\
\hline
\end{tabular}

Table.2 Treatment combinations

\begin{tabular}{|l|ll|l|ll|}
\hline $\mathbf{1}$ & JG $-\mathbf{1 6}$, & $\mathbf{3 0} \mathbf{C M}$ & $\mathbf{1}$ & JG $-\mathbf{1 6}$ & $\mathbf{4 5} \mathbf{C M}$ \\
\hline $\mathbf{2}$ & $\mathrm{JG}-315$ & $30 \mathrm{CM}$ & 2 & $\mathrm{JG}-315$ & $45 \mathrm{CM}$ \\
\hline $\mathbf{3}$ & $\mathrm{PhuleG}-405$ & $30 \mathrm{CM}$ & 3 & $\mathrm{PhuleG}-405$ & $45 \mathrm{CM}$ \\
\hline $\mathbf{4}$ & $\mathrm{JG}-36$ & $30 \mathrm{CM}$ & 4 & $\mathrm{JG}-36$ & $45 \mathrm{CM}$ \\
\hline $\mathbf{5}$ & $\mathrm{NBeG}-452$ & $30 \mathrm{CM}$ & 5 & $\mathrm{NBeG}-452$ & $45 \mathrm{CM}$ \\
\hline $\mathbf{6}$ & $\mathrm{RVG}-203$ & $30 \mathrm{CM}$ & 6 & $\mathrm{RVG}-203$ & $45 \mathrm{CM}$ \\
\hline
\end{tabular}

Table.3 Dry weight / plant (g) as influenced by genotypes and row spacing

\begin{tabular}{|c|c|c|c|c|}
\hline A Variety : 6 & 30 DAS & 60 DAS & 90 DAS & Maturity \\
\hline V1 JG-16 & 1.54 & 5.50 & 8.67 & 11.62 \\
\hline V2 JG-315 & 1.38 & 5.43 & 8.56 & 11.56 \\
\hline V3 Phule G-405 & 1.58 & 5.94 & 8.97 & 11.75 \\
\hline V4 JG-36 & 1.44 & 5.49 & 8.62 & 11.61 \\
\hline V5 NBeG-452 & 1.56 & 5.63 & 8.75 & 11.64 \\
\hline V6 RVG-203 & 1.57 & 5.78 & 8.94 & 11.70 \\
\hline S.E.m \pm & 2.29 & 4.47 & 4.88 & 4.03 \\
\hline CD5\% & 6.531 & 13.11 & 14.32 & 11.18 \\
\hline B. Spacing : 02 & & & & \\
\hline S1 : 30 cm & 1.56 & 5.74 & 8.85 & 11.71 \\
\hline S2 : 45 cm & 1.47 & 5.51 & 8.66 & 11.58 \\
\hline S.E.m \pm & 1.29 & 2.58 & 2.82 & 2.33 \\
\hline CD5\% & 3.77 & NS & 8.27 & 6.82 \\
\hline C. V $\times$ S & & & & \\
\hline S.E.m \pm & 3.14 & 6.31 & 6.90 & 5.69 \\
\hline CD5\% & 11.80 & 23.66 & 25.87 & 21.35 \\
\hline
\end{tabular}


Table.4 Interaction effect of genotype $\times$ row spacing $(\mathrm{G} \times \mathrm{S})$ on dry weight of plant $(\mathrm{g})$ at 30 DAS

\begin{tabular}{|c|c|c|}
\hline \multirow{2}{*}{ Genotypes } & \multicolumn{2}{|c|}{ Row spacing } \\
\cline { 2 - 3 } & S1 & S2 \\
\hline V1: JG 16 & 161.67 & 144.00 \\
\hline V2: JG 315 & 123.67 & 133.33 \\
\hline V3: PhuleG 405 & 179.67 & 162.67 \\
\hline V4 JG 36 & 126.00 & 138.00 \\
\hline V5: NBeG 452 & 171.00 & 151.00 \\
\hline V6: RVG 203 & 176.00 & 153.33 \\
\hline SEm \pm & 3.14 & \\
\hline CD at 5\% & 11.80 & \\
\hline
\end{tabular}

Table.5 Interaction effect of genotypes $\times$ row spacing $(\mathrm{G} \times \mathrm{S})$ on dry weight plant $(\mathrm{g})$ at 60 DAS

\begin{tabular}{|c|c|c|}
\hline \multirow{2}{*}{ Genotypes } & \multicolumn{2}{|c|}{ Row spacing } \\
\cline { 2 - 3 } & S1 & S2 \\
\hline V1: JG 16 & 569.00 & 538.00 \\
\hline V2: JG 315 & 548.33 & 529.00 \\
\hline V3: PhuleG 405 & 611.67 & 578.33 \\
\hline V4 JG 36 & 566.67 & 531.67 \\
\hline V5: NBeG 452 & 569.33 & 557.33 \\
\hline V6: RVG 203 & 584.67 & 572.33 \\
\hline SEm \pm & 6.31 & \\
\hline CD at 5\% & 23.66 & \\
\hline
\end{tabular}

Table.6 Interaction effect of genotype $\times$ row spacing $(\mathrm{G} \times \mathrm{S})$ on dry weight of plant $(\mathrm{g})$ at 90 DAS

\begin{tabular}{|c|c|c|}
\hline \multirow{2}{*}{ Genotypes } & \multicolumn{2}{|c|}{ Row spacing } \\
\cline { 2 - 3 } & S1 & S2 \\
\hline V1: JG 16 & 870.00 & 865.67 \\
\hline V2: JG 315 & 856.33 & 851.67 \\
\hline V3: PhuleG 405 & 923.00 & 875.67 \\
\hline V4 JG 36 & 861.67 & 861.67 \\
\hline V5: NBeG 452 & 890.00 & 868.67 \\
\hline V6: RVG 203 & 913.67 & 872.67 \\
\hline SEm & 6.90 & \\
\hline CD at 5\% & 25.87 & \\
\hline
\end{tabular}


Table.7 Interaction effect of genotypes $\times$ row spacing $(\mathrm{G} \times \mathrm{S})$ on dry weight plant $(\mathrm{g})$ at maturity

\begin{tabular}{|c|c|c|}
\hline \multirow{2}{*}{ Genotypes } & \multicolumn{2}{|c|}{ Row spacing } \\
\cline { 2 - 3 } & S1 & S2 \\
\hline V1: JG 16 & 1172.67 & 1156.67 \\
\hline V2: JG 315 & 1156.33 & 1147.00 \\
\hline V3: PhuleG 405 & 1190.00 & 1168.67 \\
\hline V4 JG 36 & 1161.67 & 1151.67 \\
\hline V5: NBeG 452 & 1173.33 & 1161.67 \\
\hline V6: RVG 203 & 1175.67 & 1167.33 \\
\hline SEm & 5.69 & \\
\hline CD at 5\% & 21.35 & \\
\hline
\end{tabular}

Table.8 Pods per plant, seeds per pods, seed yield per plant $(\mathrm{g})$ and seed index as influenced by genotypes and row spacing

\begin{tabular}{|c|c|c|c|c|}
\hline A. Variety : 6 & Pod/plant & Seeds/pods & $\begin{array}{l}\text { Seed yield } \\
\text { / plant (g) }\end{array}$ & $\begin{array}{c}\text { Seed index } \\
(\%)\end{array}$ \\
\hline V1 JG-16 & 47.61 & 1.42 & 10.80 & 15.98 \\
\hline V2 JG-315 & 37.44 & 1.31 & 6.76 & 13.84 \\
\hline V3 Phule G-405 & 64.00 & 1.68 & 21.34 & 19.76 \\
\hline V4 JG-36 & 44.72 & 1.40 & 9.20 & 14.74 \\
\hline V5 NBeG-452 & 53.33 & 1.45 & 13.06 & 16.92 \\
\hline V6 RVG-203 & 62.55 & 1.59 & 17.95 & 18.16 \\
\hline S.E.m \pm & 1.09 & 0.04 & 0.64 & 0.36 \\
\hline CD at $5 \%$ & 3.20 & 0.11 & 1.88 & 1.04 \\
\hline \multicolumn{5}{|l|}{ B. Spacing : 02} \\
\hline $\mathrm{S1}: 30 \mathrm{~cm}$ & 53.92 & 1.53 & 13.69 & 16.60 \\
\hline $\mathrm{S} 2: 45 \mathrm{~cm}$ & 49.29 & 1.41 & 11.46 & 16.53 \\
\hline S.E.m \pm & 0.63 & 0.02 & 0.37 & 0.21 \\
\hline CD at $5 \%$ & 1.85 & 0.07 & 1.09 & 0.60 \\
\hline \multicolumn{5}{|l|}{ C. $\mathbf{V} \times \mathbf{S}$} \\
\hline S.E.m \pm & 0.424 & 0.035 & 0.426 & 0.691 \\
\hline CD at $5 \%$ & 1.59 & NS & 1.597 & 2.592 \\
\hline
\end{tabular}


Table.9 Interaction effect of genotype $\times$ row spacing $(\mathrm{G} \times \mathrm{S})$ on pods per plant

\begin{tabular}{|c|c|c|}
\hline Genotypes & Row spacing & \\
\hline & S1 & S2 \\
\hline V1: JG 16 & 50.28 & 44.94 \\
\hline V2: JG 315 & 39.06 & 35.18 \\
\hline V3: PhuleG 405 & 66.67 & 61.33 \\
\hline V4 JG 36 & 47.38 & 42.06 \\
\hline V5: NBeG 452 & 55.92 & 50.74 \\
\hline V6: RVG 203 & 64.22 & 60.88 \\
\hline SEm \pm & 0.424 & \\
\hline CD at 5\% & 1.593 & \\
\hline
\end{tabular}

Table.10 Interaction effect of genotypes $\times$ row spacing $(\mathrm{G} \times \mathrm{S})$ on seed yield per plant $(\mathrm{g})$

\begin{tabular}{|c|c|c|}
\hline Genotypes & Row spacing & S2 \\
\hline V1: JG 16 & S1 & 8.80 \\
\hline V2: JG 315 & 12.80 & 5.67 \\
\hline V3: PhuleG 405 & 7.67 & 19.34 \\
\hline V4 JG 36 & 23.34 & 8.20 \\
\hline V5: NBeG 452 & 10.20 & 11.06 \\
\hline V6: RVG 203 & 15.06 & 15.95 \\
\hline SEm \pm & 19.95 & \\
\hline CD at 5\% & 0.426 & \\
\hline
\end{tabular}

Genotype PhuleG 405 with $30 \mathrm{~cm}$ row spacing gave significantly higher pods/plant (Table 9) than rest of other interactions.

\section{Seeds / pod (No.)}

Number of seeds per pod did significantly influenced by genotypes and row spacing. However, it varied from 1.68 to 1.31 in respect of genotypes and row spacing (Table 8). The seeds per pod were significantly superior in PhuleG 405 (1.68) than other genotypes except RVG 203. The seeds per pod is significantly higher with $30 \mathrm{~cm}$ row spacing.

\section{Seed yield / plant}

Seed yield per plant of chickpea significantly varied due to different genotypes and row spacing. Perusal of data given in (Table 8) indicated that the genotypes PhuleG 405 gave significantly higher yield/plant than by RVG 203, NBeG 452, JG 16, JG 36 and JG 315 (Iman et al., 2013). The $30 \mathrm{~cm}$ row spacing significantly increased the seed yield / plant $(13.69 \mathrm{~g})$ as compared to (11.46 g) under 45 $\mathrm{cm}$ row spacing. The interaction between genotypes and row spacing $(\mathrm{GxS})$ was found significant. Genotypes PhuleG 405 with $30 \mathrm{~cm}$ row spacing was significantly higher in seed yield/plant (Table 10) than rest of the interactions.

\section{References}

Ahamad Khan, E. Aslam, M, Ahmad, H., Himayatullah, K., Khan, M. and Hussain, A. (2010). Effect of row spacing and seeding rates on growth, 
yield and yield component of chickpea. Sarhad Journal of Agric., 26 (2): 201211.

Azadi, Iman, Pezeshkpour, Payam and Nasrollahi, Hadis (2013). Evaluation the effect of planting season and crop density on yield and yield density of lentil (ghachsaran variety) in the dry land condition. Annals of Biological Research; 4 (2):47-50

Beech, D.F. and G.J. Leech (1989). Effect of plant density and row spacing to the yield of chickpea. (CV. Tyson). Field Crop Abst. 42 (11) : 1091.

Biabani, A. (2011). Effect of plant density on yield and yield component of chickpea (Cicer arietinum L.) grown under environmental condition of Golestan, Iran. J. Agric. Sci. and Tech. 5: 32-33

Goyal Suresh, Verma H.D. and Nawange D.D. (2010). Studied on growth and yield of kabuli chickpea (Cicer arietinum L.) genotype under different plant densities and fertility levels. Legume Research 33 (3) : 221-223.

Sabagpour, S.H., Pezeshkpour, P., Sarparast, R., Saeed, A., Safikhani, M., Hashembeig, A. and Karami, I.(2010).
Study of seed yield stability in chickpea (Cicer arietinum L.) genotype in autumn planting in dryland conditions. Seed and Plant Improvement Journal 26 (1\&2) : 173:191.

Shamsi, K., Kobraee, S. and Rasekhi, B. (2011) "The effects of different planting densities on seed yield and quantitative traits of rainfed chickpea (Cicer arietinum L.) varieties". African Journal of Agricultural.6 (3) : 655-659

Sharma, J. and Dadheech, R.C. (1986). Performance of new chickpea genotype under different dates of planting and row spacing. Agric. Sci. Digest. 6 : 181-183

Syed, M.A., Islam M.R., Hossain M.S., Islam M.M. and Amin M.N. (2012). Genetic divergence in chickpea Bangladesh $J$. of Agric. Res., 37 (1): 129-136.

Verma, C.B. Yadav, R.S., Singh, I.J. and Singh, A.K. (2009). Physiological traits and productivity of rain fed chickpea in relation to genotypes. Legume Research, 32 (2): 103-107.

\section{How to cite this article:}

Usha Waskle, R.P. Singh and Megha Dubey. 2019. Interaction Effect of Genotype and Row Spacing in Chickpea and its Post Harvest Studies. Int.J.Curr.Microbiol.App.Sci. 8(11): 19921999. doi: https://doi.org/10.20546/ijcmas.2019.811.233 